\title{
Irritable Bowel Syndrome: A Case Study
}

\author{
Nadia Sutanto and Edgar Jeremy \\ Faculty of Psychology \\ Universitas Surabaya
}

\begin{abstract}
Irritable Bowel Syndrome (IBS) is a functional disorder marked by some gastrointestinal symptoms frequently associated with extradigestive symptoms with unknown organic causes. In this study the authors investigated whether IBS causes psychological symptoms or vice versa. Data were collected through an in-depth interview (anamnesis), a hetero-anamnesis, and the Depression Anxiety Stress Scale (DASS-21). The subject was a 20-year-old student (D) diagnosed with IBS since the age of 15. Results showed that the subject had an extremely severe anxiety and stress, and moderate depression. The main obstacle faced by the subject was his escape-avoidance coping strategies which were not appropriately applied in solving problems. This situated the subject in a vicious cycle between recurrent IBS, helplessness, avoidance of responsibility, and anxious/stressful conditions. The subject's type of personality which tended to be introverted and neurotic made him experience difficulties in overcoming psychosocial stressors, such as academic demands and lack of social relationships. The psychological factors influenced the psychological states of the subject that resulted in the recurrence of IBS.
\end{abstract}

Keywords: irritable bowel syndrome, depression, anxiety, stress

Irritable Bowel Syndrome (IBS) adalah gangguan fungsional yang ditandai beberapa gejala gastrointestinal yang sering diasosiasikan dengan gejala extradigestive dengan penyebab organik yang belum diketahui. Dalam studi ini para penulis meneliti apakah faktor psikologi meningkatkan gejala IBS atau sebaliknya Studi ini mengumpulkan data melalui wawancara (auto-anamnesis, hetero-anamnesis), dan data terkait faktor-faktor psikologis. Data didukung Depression Anxiety Stress Scale (DASS21). Subjek adalah mahasiswa (D) berusia 20 tahun yang telah didiagnosis menderita IBS sejak berusia 15 tahun. Hasil menunjukkan subjek memiliki kecemasan dan stres amat ekstrem, serta depresi yang moderat. Kendala utama subjek adalah strategi coping escape-avoidance yang tidak tepat dalam menyelesaikan masalah. Situasi ini membuat subjek terjebak dalam "lingkaran tak berujung pangkal" antara kambuhnya gejala IBS, keputusasaan, penghindaran tanggung jawab, dan kecemasan/stres. Tipe kepribadian subjek yang cenderung introvert dan neurotik membuatnya semakin sulit mengatasi stresor psikososial berupa tuntutan akademik dan kurangnya relasi sosial subjek dan teman-temannya. Faktor-faktor psikologis tersebut berpengaruh pada keadaan psikologis subjek yang berakibat pada munculnya gejala IBS secara berulang kali.

Kata kunci: irritable bowel syndrome, depresi, kecemasan, stres

Irritable Bowel Syndrome (IBS) is a cronic condition in the digestive system (Ford, Brandt, Young, Chey, Foxx-Orenstein, \& Moayyadi, 2009; Fukudo et al., 2015; Thompson, 2016; \& Wald, 2016) that is accompanied by abdominal pain, discomfort associated with defecation, and the sensation of bloating (Chey, Kurlander, \& Eswaran, 2015; Makharia, Catassi, \& Makharia, 2015; \& Thompson, 2016).

Correspondence concerning this article should be addressed to Nadia Sutanto, Faculty of Psychology Universitas Surabaya, Jalan Raya Rungkut Mejoyo, Surabaya 60293. Email: namaku.nadia@gmail.com
Pathophysiologically, this is caused by several conditions, including abnormality in the spontaneity of digestive performance, sensations related to internal organs (particularly the intestines), brain-gut interactions, excess mucus production in the intestines that activates immunity, increase in intestinal absorption, tolerance to certain foods, exposure to infections, antibiotic consumption, psychosocial distress (early-life abuse/stressors), and perception of pain (Thompson, 2016; Chey, Kurlander, \& Eswaran, 2015). Tosic-Golubovic, Miljkovic, Nagorni, 
Lazarevic, and Nikolic (2010) and Creed and Guthrie (1987) defined IBS as a functional disorder marked by several gastrointestinal symptoms that are often associated with extradigestive symptoms with unknown organic causes. Based on the recent studies of IBS, the World Gastroenterology Organization (2015) states that IBS is a functional digestive disorder with various causes.

The general symptoms that are often complained by the patients are constipation, full stomach feeling, abdominal bloating, and diarrhea (Drossman, Camilleri, Mayer, \& Whitehead, 2002). The most significant standardization of IBS diagnosis was prepared by a group of researchers led by Manning (Manning, Thompson, Heaton, \& Morris, 1978). Manning et al. arranged an algorithm consisting of questions used as the basis of IBS inventory, namely the Manning Criteria. The Manning Criteria consists of: (1) onset of pain related to more frequent defecation; (2) looser stool with onset of pain; (3) pain relieved by defecation; (4) abdominal bloating; (5) feeling unsatisfied after defecation in more than $25 \%$ of the total of defecations; and (6) diarrhea with mucus in more than $25 \%$ of the total defecations. Further development of the standardization of IBS diagnosis became the topic of research in order to provide scientific evidence for diagnosis and treatment of Functional Gastrointestinal Disorders. The results of this investigation were the Rome Criteria. The Rome Criteria developed according to researchers' findings were categorized into three stages, that is, Rome I Criteria developed in 1992, Rome II Criteria developed in 1999, and Rome III Criteria developed in 2006. For diagnosing IBS, the Rome III Diagnostic Criteria focuses on the frequency of defecation and appearance of stool. The Rome III Criteria was commonly used in China where IBS patients complained about the pain in the upper area of stomach, or a spinning sensation of pain in the stomach or in the lower-left part of the stomach with continous or changing pain (World Gastroenterology Organization, 2015). A survey conducted by Fukudo et al. (2015) showed that the percentage of IBS patients in Indonesia was $8.0 \%$ of the total number of participants in East Asia, the patients complained of their pain, discomfort feeling, as well as constipation/diarrhea.

The Rome III Criteria classified IBS based on the symptoms that are often experienced by the patients. IBS with constipation is categorized as IBSC, IBS with diarrhea is categorized as IBS-D, and the combination of the two symptoms is categorized as IBS-A (Malagelada, 2006; Cash, Schoenfeld, \& Chey, 2002). Based on the Rome II Criteria, IBS-C is identified from the appearance of patient's stools. Based on the available cases of IBS-C, more than $25 \%$ of patients had solid stools and less than $25 \%$ had watery stools. This was found in more than a third of the cases, and more commonly in women. Based on the Rome II Criteria, IBS-D can also be identified from the patients' stools; less than $25 \%$ of the available cases of IBS-D had solid stools and more than $25 \%$ hadwatery stools, this was found in more than a third of the cases, and more frequently among men.

IBS is often experienced by individuals aged 1565 years old, with the age of onset based on a doctor's visits of 30-50 years old (World Gastroenterology Organization, 2015). The prevalence of IBS is more common among women than men although as stated above, IBS-D is more common among men. Children also have the possibility of developing IBS.

Several studies showed that $70-90 \%$ of IBS patients that searched for medical help had comorbidity with mental disorders, such as mood disorder, anxiety disorder, and somatic disorder (Fullwood \& Drossman; Longstreth; Lydiard, cited in Tosic-Golubovic et al., 2010). There were additional data supporting the relationships between psychological symptoms and IBS. In Mexico, 70\% of IBS patients were diagnosed with anxiety disorder, $46 \%$ with depression, and 40-\% with both (Quigley, 2009). Chaudhary and Truelove (cited in Creed \& Ththrie, 1987) identified psychological factors affecting the onset of IBS in more than $80 \%$ of 130 cases that they encountered. Based on the findings that there were correlations between psychological factors and IBS, IBS patients need psychological treatments instead of relying merely on medical treatments. Psychotherapy is important in treating IBS patients because technically there is no medicine that can directly cure IBS. Psychological factors, such as personality structure, have been frequently overlooked or unnoticed by previous researchers (Olden, cited in Farnam, Somi, Sarami, \& Farhang, 2008).

Socio-cultural factor has also become an important factor that should be considered because different countries have different impacts on the form of IBS (Fukudo et al., 2015). Social life in a country, town, and region can be a stressor. Environmental stressors have been found to influence the symptoms of IBS. Graff (2015) explains that acute and chronicstressors, such as assignment deadlines, exams, work interviews, interpersonal conflicts, fi- 
nancial problems, and family problems can affect the work of human digestive system. Research on the patients of gastroenterology clinic indicated that life-threatening events, such as divorces and breakups, often precede the onset of functional digestive disorder (Creed \& Guthrie, 1987). Stress can arise from an individual's appraisal on his or her life events (Lazarus, cited in J. Feist \& G. J. Feist, 2009). An individual's appraisal on an event (stimulus) is affected by perception, therefore a stimulus is perceived as a stressor in a subjective way, it is based on each individual's experiences and appraisals.

The research conducted by Chang (2011) states that many patients complained that the symptoms of IBS emerged upon dealing with stressful situations. The World Gastroenterology Organization (2015) found that psychological distress, life events, and negative coping styleplay an important role in IBS pathogenesis. In relation to psychosocial distress, Walker, Katon, and Jemelka's research, that is cited by Creed and Guthrie (1987) indicated the high levels of comorbidity between IBS and mental disorders, indicating that affective symptoms might be a specific and integral parts of IBS. One of the impacts of stress in an individual is anxiety (Goldberg, 2014). Anxiety due to stress that may cause abdominal pain has been the topic of discussion in both medical and psychological settings. Additionally, an individual experiencing chronic stress is most likely having depression (Baum \& Polsusnzy, 1999). The relationships between stress, anxiety, and depression have been found in IBS patients. The purpose of this study was to investigate whether stressful conditions experienced by the patient aggravated the symptoms of IBS or whether IBS ignite the psychological problems.

\section{Method}

To identify psychological states of informants, we used a qualitative approach using semi-structured interviews and assessments of depression, anxiety, and stress. Interview was conducted to explore the underlying factors that induce stress, anxiety, and depression as measured by the Depression Anxiety Stress Scale 21 (DASS-21) developed by S. H. Lovibond and P. F. Lovibond (1995). The DASS-21 consists of 21 items that measure the levels of depression, anxiety, and stress (Table 1).

The depression scale includes aspects measuring dysphoria, life devaluation, self-denial, loss of inte-
Table 1

Blueprint of DASS-21

\begin{tabular}{lcr}
\hline No. & Aspects & Items \\
\hline 1. & Depression & $3,5,10,13,16,17,21$ \\
2. & Anxiety & $2,4,7,9,15,19,20$ \\
3. & Stress & $1,6,8,11,12,14,18$ \\
\hline
\end{tabular}

rest/involvement, anhedonia, and inertia. The anxiety scale includes aspects measuring autonomic arousal, skeletal muscle effects, situational anxiety, and subjective experience of anxious affect. The stress scale focuses on non-chronic arousal indicated by difficulty to relax, nervous, and prone to anger/disappointment, easily offended/over-reaction, and impatience. The DASS-21 can measure the severity level of depression, anxiety, and stress of an individual. The severity is categorized into five categories: normal, mild, moderate, severe, and extremely severe. The scoring guide of the DASS-21 can be seen in Table 2.

The informant ( $\mathrm{D}$, male, 20 years old) has been diagnosed with IBS by a doctor and D reported the symptoms of IBS in line with the Manning and Rome III Criteria (Table 3). In addition to the two criteria, the Visual Analog Scale and Comparative Pain Scale were used to measure D's perception on the pain that he experienced during IBS symptoms. As this study used a qualitative approach, we also conducted a triangulation with D's mother. Other family members refused to be involved in the study. This did not become a barrier for obtaining credible information, considering that his mother was a significant person to $\mathrm{D}$ and she had been involved in almost all aspects of D's life. D's involvement in this study started with the signing of the informed consent.

\section{Results}

Prior to measuring D's despression, stress, and anxiety, D's symptoms were examined using the Manning and Rome III Criteria as follows.

\section{Pain}

D complained that he frequently had abdominal pain. He experienced this for a long time, and therefore it could be categorized as a chronic pain. The pain that $\mathrm{D}$ felt was intermittent (coming and going) and reduced after defecation. The Visual Analog Scale showed that D's level of pain was at $70 \%$, 
Table2

Categories in the Depression Anxiety Stress Scale 21

\begin{tabular}{cccc}
\hline Severity Level & Depression & Anxiety & Stress \\
\hline Normal & $0-4$ & $0-3$ & $0-7$ \\
Mild & $5-6$ & $4-5$ & $8-9$ \\
Moderate & $7-10$ & $6-7$ & $10-12$ \\
Severe & $11-13$ & $8-9$ & $13-16$ \\
Extremely Severe & $14+$ & $10+$ & $17+$ \\
\hline
\end{tabular}

Note. Source: S. H. Lovibond \& P. F. Lovibond, 1995

\section{Table 3}

Manning \& ROME III Diagnosis Criteria

\begin{tabular}{cl}
\hline Manning & $\begin{array}{l}\text { Onset of pain related to more frequent defecation } \\
\text { Looser stool with onset of pain } \\
\text { Pain relieved by defecation } \\
\text { Abdominal bloating } \\
\text { Feeling unsatisfied after defecation in more than } 25 \% \text { of total defecations } \\
\text { Diarrhea with mucus in more than } 25 \% \text { of total defecations }\end{array}$ \\
ROME III & $\begin{array}{l}\text { Stomach pain or discomfort, at least three days in a month in the last three months } \\
\text { a. Improvement with defecation } \\
\text { b. Onset of symptoms with a change in frequency of defecation } \\
\text { c. Onset of symptoms with a changein appearance of stool }\end{array}$ \\
\end{tabular}

while based on the Comparative Pain Scale, the pain felt by $\mathrm{D}$ was at level 6 . It can be concluded that the pain felt by $\mathrm{D}$ was strong, $\mathrm{D}$ even perceived this as a sharp pain, making him unable to think clearly and disrupting his daily activities, including his social relationships. Ten days prior to screening, D stated that he had pain episodes for the whole ten days. To reduce this pain, D consumed several pain killers, such as Cargesik®, Tradosik $®$ dan Ponstan (®. D admitted that the medicines were effective, but D was uncomfortable with the side effects of the medicines, which were in the forms of discomfort feeling, from the head to joints. This pain had caused him feeling distressed, making him to damage the items around him because of the unsubsiding pain.

\section{Bloating}

D also complained of bloating that emerged with the pain. He explained that his stomach seemed to expand and the bloating could emerge suddenly and unrelated to any specific situation. On the Visual Analog scale, the level of bloating experienced by $\mathrm{D}$ was at $40 \%$, particularly after consuming the antibloating medicine: Gazero®. In the morning before going to the university, $\mathrm{D}$ admitted that the bloating level was at $60 \%$. Taking anti-bloating medicine was helpful in reducing the feeling of bloating, especi- ally after defecation or flatulence. D believed that the cause of bloating was drinking a large amout of water, thus, making him to reduce his water consumption. In the 14 days before screening, D admitted that he had the bloating for 14 days, but full stomach feeling was only experienced for three days. According to $\mathrm{D}$, he had ever experienced severe level of bloating. D also experienced borborygmi (stomach rumbling) during bloating, but the frequency was low. He even admitted that the rumbling could be heard. D felt his stomach was full of gas and after flatulence, D had the bloating and his stomach pain subsided. When D felt severe bloating, the frequency of flatulence increased and D sometimes had to defecate.

\section{Diarrhea}

D complained of diarrhea when he had the stomach pain. D explained that when his stomach was painful, he had watery stools without any solid pieces. Medicines that helped him were Diatabs ${ }^{\circledR}$, Diapet ${ }^{\circledR}$ or Norit $\AA$, which basically medicines for diarrhea. D also drank Oralit with the medicines. During diarrhea, D felt nauseous, dizzy, losing appetite, and languid, prompting $\mathrm{D}$ to walk using a walking stick. On the 14 days before screening, D admitted that he had diarrhea. D stated that eating 
Table 4

Results of DASS-21

\begin{tabular}{llll}
\hline No. & Aspects & Score & Category \\
\hline 1. & Depression & 10 & Moderate \\
2. & Anxiety & 16 & Extremely severe \\
3. & Stress & 20 & Extremely severe \\
\hline
\end{tabular}

spicy food was the trigger. D had difficulties holding his bowel movement and defecated in his pants.

\section{Nausea and Vomiting}

$\mathrm{D}$ admitted that during diarrhea, he felt like having the vomit-and-diarrhea disease, because it came with nausea. D even had to vomit as he could not hold back the nausea. In the 14 days before screening, $\mathrm{D}$ had nausea for approximately eight days. D felt that the nausea was worse when D was in the seating position, thus, he chose to stand. D consumed peppermints to reduce his nausea.

\section{Constipation}

D also had constipation, although the frequency was lower than diarrhea. During constipation, D admitted that there was a feeling of incomplete defecation, still bloating, and uncomfortable feeling in his body. During constipation, D felt anxious because of worrying of having an operation and therefore, he was reluctant to eat as he imagined his stomach was already full. D had to strain during bowel movements to release stools. To help with defecation, D consumed a papaya mixed with lime and also drank Vegeta ${ }^{\circledR}$ as a fiber intake.

The results of screening indicated that $\mathrm{D}$ met all the criteria of IBS based on the Manning and RomeIII Criteria. D suffered from IBS with predominant diarrhea (IBS-D).

The results of DASS-21 showed that D had extremely severe anxiety and stress, and moderate depression (see Table 4).

\section{Discussion}

In general, prolonged stress causes an individual to become anxious, while untreated anxiety may cause an individual to become depression. D experienced this condition that will be described as follows.

D experienced extremely severe stress according to the DASS-21 category, and according to Lahey (2007), this might be caused by one or several sour- ces of stress, such as frustration, changes, pressures, physiology, and environment. An individual can experience frustration if $\mathrm{s} / \mathrm{he}$ often fails to achieve what $s /$ he wants. Repeated failures experienced by $\mathrm{D}$ in facing the changes and pressures might cause frustration. This long-term frustration resulted in chronic stress.

The results of previous studies indicated that individuals with chronic stress related to interpersonal relations experienced frustration, causing longer IBS symptoms compared to IBS patients without interpersonal relationship problems (Gwee et al., 1999, cited in Kiamarsi \& Abolghasemi, 2010). D also experienced interpersonal relationship problems but he still had social interests and valued friendships.

"Friends cannot be explained in words. The bottom line is I need them and without them, I feel that something is missing. A close friend gives me support and raise my spirit." (D66 \& 69)

"Teman itu lebih tidak saya jelaskan dengan kata-kata. Pokoknya saya butuh itu dan kalau tanpa itu saya rasanya kayak ada yang kurang gitu lo... Teman dekat saya itu kasih dukungan dan naikin spiritnya saya gitu." (D66 \& 69)

In reality, D had difficulties in making friends in his university. D admitted that he had the interest to make friends, but D lacked social competence. This is because he had different interests, hobbies, and type of personality in compared to his university friends. D thought that his friends were extroverted (D133) while D was introverted. This became obstacles when he had to do a group work. The obstacles in studying or doing a group work have become the stressor for D, because D had a high standard for his own academic performance.

"Honestly, I am still confused. With fellow students, I only know one or two people, and I rarely talk to them." (D4)

"For example, in socialization with peers. I am too awkward, so I am confused." (D168)

"This makes me stressed, but not directly, this is not a social problem. Well, for example, my social skill is lacking, so automatically I have difficulties in finding groups to study with. Then studying becomes difficult, something like that." (D168)

"Because of this sickness I have difficulties doing general things, such as going to school, well automatically the effect is my socialization with peers becomes limited, during puberty this is an important phase. Well, because of this, I'm like this. For exam- 
ple, when I'm with peers, I feel awkward.” (D4)

"Saya masih bingung jujur. Sama murid pun cuma kenal satu-dua orang, itu pun jarang bicaranya." (D4)

"Misalnya ya kayak ini aku sosialisasi sama teman sebaya. Aku 'kan kaku, bingung aku.” (D168)

"Jadi itu akan buat aku stres tapi bukan secara langsung, bukan masalah sosialnya. Nah gini misalnya kemampuan sosialku kurang misalnya otomatis aku belajar kelompoknya susah nyari kerja kelompoknya "kan. Ya jadi kena, belajarnya jadi susah, gitu lo." (D168)

"Itu 'kan karena sakit ini saya jadi kesulitan melakukan hal-hal standar misalnya kayak pergi ke sekolah, nah otomatis imbasnya sosialisasi saya dengan teman sebaya jadi terbatas, saya zaman pubertas remaja 'kan itu 'kan fase yang yang penting. Nah itu karena peristiwa ini, saya seperti ini. Ya kayak misalnya kalau sama teman sebaya jadi kaku gitu." (D4)

D explained that the IBS symptoms he had was the main reason he could not attend classes and this resulted in his lacks of social skills. Wilson et al. (2004) state that IBS can make a significant impact on the lives of patients directly and indirectly, such as decreasing of patients' social interaction and quality of life. The lack of social support from peers might reduce D's quality of life. This low quality of life due to the lack of social support could induce stress that in turn, might trigger or worsen D's IBS symptoms.

Life changes can also cause stress due to the need of adjustment (Lahey, 2007). Both planned and sudden changes can cause stress. D experienced changes that made him have chronic stress indicated by the presence of IBS symptoms. Although it is most likely that IBS symptoms were not the main cause of his problems, pain and discomfort feeling from the symptoms had been the main sources of D's problems. Changes in his physical condition were D's main sources of stress, particularly in the aspects of affection and cognition. Furthermore, D had the pressures from internal and external factors (Lahey). D and his family had certain expectations that required $\mathrm{D}$ to act against this certain standard to reach the quality of life as expected by all.

"Long time ago, before the national examination, I was okay with exams. Just a little bit afraid, the fear level was only 'oh, no, what will happen in tomorrow's test, what should I do?" but afterwards, during the national examination, I feel like it's really a life changer. This is an important factor that changes my life." (D116)

"Dulu itu sebelum UNAS, saya sama ujian itu biasa-biasa aja. Cuma takut ya biasa aja, cuma kayak levelnya "waduh, besok ujian, gimana?!" tapi setelah itu sama pas saya UNAS itu, saya benar-benar sudah kayak yang pengubah hidup saya. Suatu faktor penting pengubah hidup saya gitu." (D116)

In terms of affective and cognitive states (Sarafino, 2006), D felt the pressures of studying both from the internal (self) and external (family) sources. D expected that he would successfully pass the exam. But in the pressured condition, he experienced IBS symptoms that caused him feeling unbearable pain and making him faint. D believed that the IBS symptoms had made him difficult to think clearly (D called this as a mental breakdown) and caused him to feel angry at himself. In different threatening situations, D tended to lose his calmness and seemed to overreact (DASS-21).

This condition indicated that he had not only experienced severe stress, but also anxiety.

"I'd been in a state of terrible relapse, it's at the severe level. Painkillersdidn't work. I ended up homeschooling (learning at home), biting my pillow because of the pain. I remember I only slept for only one or two hours. Even then it's not comfortable. I was sick but I had the pressure to continue studying so I could graduate. The pressure got higher because I fainted during the national exam, I fainted. I was very scared, having a mental breakdown. Then I cried until my whole body's shivering." (D117)

"Itu saya sudah dalam keadaan kambuh yang mengerikan, anggapannya sampai level tinggi gitu. Sampai pain killer itu nggak mempan. Itu belajar itu sampai, itu saya home schooling, sampai gigit guling, saking sakitnya. Saya masih inget itu, tidur cuma satu jam, dua jam. Saya tidur pun nggak nyaman sekali. Sakit dengan beban saya ingin belajar terus agar bisa lulus gitu. Belum lagi tambah berat karena saya pingsan pas UNAS saya pingsan. Saya tambah super duper takut Saya mental break gitu. Akhirnya saya nangis, sampai tubuh saya gemetar semua." (D117)

D could not hold his sadness and anger and this made him at times overreact and ignore surroundings, destroying items that D had (conative). When 
pain mingled with anxiety, D had difficulities in controlling his mind and could not make reasonable and effective decisions.

"In the past, when I was angry, I swore. At that time I like to swear and punch my own stomach while cursing. Destroying things. I could not accept myself, why I become like this? Damn.” (D59)

"Dulu sempat marah kayak misuh gitu, zaman itu kan aku jadi misuh-misuh sampai mukul-mukul perutku sendiri dulu. Hancur-hancurin barang gitu. Nggak terima sama diri sendiri kayaknya, kenapa jadi kayak gini? Asem gitu." (D59)

D's current problem was the number of subjects and credit points that he needed to take (insisted by D's mother) that were different from the advice given by D's academic advisor. D listened to his advisor's explanations that reminded him about assignments apart from lectures. As an IBS patient that could have sudden digestive problems, D felt difficulties in taking three subjects. D overreacted to having an extra subject with six credit points.

"Now it's messed up, I do not follow the advice of my academic advisor. I'm doing three subjects, with two of them had six credit points. Even though my advisor has told me to take only one subject, do not underestimate six credit points, there will be lots of assignments apart from the lectures." (D124)

"Sekarang 'kan kacau saya nggak ngikutin saran dari dosen wali saya. Langsung genjot tiga mata kuliah, khususnya yang enam sks itu dua mata kuliah. Padahal dianjurkan sama dosen wali saya satu dulu, soalnya enam sks itu jangan dianggap remeh, banyak kerja-kerja di luar kuliah gitu." (D124)

In the interview with D's mother, D blamed his mother who motivated him (the term used was "asked") to take three subjects. D became angry at his mother for a longer period of time. D's mother stated during her interview that she did not insist D to have a higher GPA, the average marks would be sufficient. For his mother, what was the most important was his son graduated from the university. Therefore, if D took only few subjects, D and his mother were worried that D would not pass the first phase of study evaluation. D also considered this issue and therefore, any decision that he chose would not make him feel calm, but made him even more anxious when thinking about his study. If D took the subjects, D felt incapable in dealing with lectures and assignments given. However, if D failed to meet the number of credit points required, he was worried that he would not pass the first phase of study evaluation.

"...the first two years is worrying, not sure if I pass or not. That's the 36 credit points. I am afraid of repeating the subjects, everything seems to mess up." (D42)

“... ini aku dua tahun pertama ini lulus apa nggak ini. Ya itu yang 36 sks. Aku juga ini takutnya ngulang apa nggak serba hancur gini kok." (D42)

\section{Anxiety}

Prolonged stress, particularly D's feeling of being taken away from D's main purpose, caused him to have anxiety. D had an irrational desire to rule the world with D's paradigm. D's biggest desire was to travel around the world and rule the world. One way to meet his desire was to successfully finish his study according to D's standards. But the presence of IBS symptoms disturbed him and destroyed D's desires, making him afraid of imagining the future. In reality, IBS symptoms can be improved with positive thinking, orientating to problem solving and avoiding overthinking. Clark and Beck (2010) explain that during the period of high level of stress, individuals often think rigidly and stubbornly that will continuously increase the feeling of threat and being in danger (which is unrealistic). The largest threat for D was his IBS symptoms developed into a severe illness leading to death.

"I am afraid of not being able to enjoy the world. I often think that if I suddenly, if my illness is as bad as cancer. I feel fear for a while because I still want to enjoy the world, I don't want to die yet. I can't enjoy the world as I want. I'm trapped in one country." (D63)

"Takut nggak bisa menikmati dunia gitu lo. Aku sempat mikir kalau misalnya aku tiba-tiba mungkin misalnya sakit ku ini, kalau sakitku keras kayak kanker gitu. Ya sempet ada ketakutan. Soalnya aku masih mau nikmati dunia, gak mau mati dulu. Kan aku ga bisa sembarangan nikmati dunia. Aku kan terperangkap di satu negara." (D63)

The fear of death expressed by D was not the death itself but the fear of failure to enjoy the world and rule it. The limitations that D over-embraced 
made him think that he was trapped in a country. D was not aware of his irrational anxiety-thoughts, strong emotional involvement made such thoughts difficult to ignore (Clark \& Beck, 2010). D's unawareness revealed in the following interview quotes.

"I am not satisfied yet because I want to grab the world. My academic advisor said that just two subjects with six credit points would be enough. My marks were down because of my illness. I could do it, but because of this illness, my performance dropped. Because of the illness, my performance during test was bad. So it's not today to grab the world, just like in the Game of Thrones." (D8)

"Saya juga belum puas karena ingin cengkram dunia. Dosen wali bilang cukup dua saja yang 6 sks. Nilai ujian saya juga menurun karena sakit. Saya bisa, namun karena sakit performa saya jadi menurun. Gara-gara sakit itu performa kerja ujian jadi tumpul. Jadi cengkram dunia juga kayak not today gitu kayak Game of Thrones." (D8)

"I don't chase the world standard. The world standard is what I said before: being born, studying, working, then dying. I basically want to enjoy the world, grab the world. I don't want to be like in a novel or an article, if I am not mistaken. The world is grey, life is just like this. I want the world to be colorful. I get bored easily. In this world, I don't follow straight roads, but follow winding roads. Thinking outside the logic, like Nikola Tesla. His views were futuristic and out of the box, his thoughts were underestimated by people and considered as fantasy, but he then proved that his technology was far more advanced." (D11)

"Aku itu nggak ngejar standar dunia. Standar dunia itu yang aku bilang dulu. Lahir, sekolah, kerja, mati. Aku pokoknya mau nikmati dunia itu, cengkram dunia. Aku ga mau kayak di novel atau artikel kalau tidak salah. Dunia itu abu-abu, hidup cuma gini dong. Aku mau dunia warnawarni. Aku cepet bosen. Aku ga nuruti ga ikuti jalan dunia lurus, jadi berbelok-belok. Kayak mikir diluar dari fase logis, kayak Nikola Tesla. Pandangannya futuristik dan di luar kotak. Pikirannya diremehkan orang dan dianggap fantasi. Tapi bisa membuktikan teknologinya maju sekali." (D11)
"For sure, I don't believe people that want to change the world. They only want to satisfy themselves. I still have thirst for power. Power can be in the form of money, fame, because from my experience, changing the world without ha-ving a power is impossible." (D15)

"Yang pasti saya itu saya kayak gak gampang percaya sama orang-orang yang ingin mengubah dunia. Padahal dia sendiri Cuma pingin muasin diri sendiri, terus apa ya. Saya itu masih ada rasa agak haus sama namanya power. Power kan bisa bentuknya duit, pamor, soalnya dari pengalaman juga kalau nggak ada power gitu mengubah dunia itu mendekati mustahil." (D15)

D continued expressing his desires to enjoy and rule the world as if it was normal and reasonable. According to Freud (cited in Schultz, 1986), D's anxiety can be categorized as neurosis. Having power is a desire dominated by the Id which is a desire to satisfy instinctual drive in order to survive. Further observation indicated that $\mathrm{D}$ associated his desire of ruling the world with academic life. The relationships between these two were not explained well by $\mathrm{D}$ who was being preoccupied with his worries about everything based on his own views.

D's anxiety was a response to the threat that he did not clearly recognize (Carpenito, 2000). This caused D to have difficulties in solving problems completely. His problems were related to his thoughts which then affected his affection and finally his actions that worsen D's IBS symptoms and psychological conditions.

According to Stuart and Sundeen (1998), anxiety that is categorized as severe could make D become too focused on his desire to grab the world. D could not divert his attention from his desire to change the world. The events that $\mathrm{D}$ appraised as causing these difficulties were, for example, a chronic illness (IBS) and academic problems, this had made D feel threatened in reaching his goals. D became more anxious because of the presence of IBS symptoms, the symptoms became even worse because of his anxiety.

"Currently, it's the external affecting the internal. If I were not sick, my internal would be able manage this problem even though it's just an average, my achievement was average. But because of this illness, my internal is attacked. So my internal isn't in the equilibrium state. It's chaotic. Feeling anxious, scared. Before it's just the external 
that battled, like a war, kamikaze, but afterwards my 'fortress' is also destroyed. So now it's about my external and internal." (D21)

"Sekarang ini sih dari eksternal memengaruhi internal. Kalau aku nggak sakit, internalku mampulah walaupun mungkin standar aja, prestasinya biasa-biasa aja. Tapi karena sakit ini, internalku juga terserang ini. Akhirnya internalku juga ga terequilibrium lagi. Jadi kacau. Gelisah-gelisah gitu, takut. Kalau dulu cuma eksternal aja kayak perang, kamikaze tapi setelah itu "benteng" $k u$ juga runtuh. Makanya sekarang eksternal dan internalku." (D21)

Franklin, Riggs, and Pai explain that irrational thinking is originated from an obsession. The belief in one obsession can create a real fear, allowing the anxiety to develop into a ritual (cited in Clark \& Beck, 2010). Zeidner (1998) explains the difference between anxiety and depression. Individuals with anxiety have lower coping skills, while individuals with depression are busy thinking about their failures and ruined relationships. Based on his statement in D63, D did not have practical steps to solve his problems, he only diverted his attention by listening to music.

"Dealing with fear ...cannot enjoy the world, but I don't have a real example. I only listen to music because problems usually stay for a while and then they will disappear." (D63)

"Mengatasi ketakutan nggak bisa menikmati dunia, tapi kalau contoh konkret kayaknya belum. Aku Cuma dengerin musik karena kalau masalah itu parasitnya nempel sejenak lalu hilang." (D63)

\section{Depression}

D's depression was categorized as medium, indicating that $\mathrm{D}$ had a potential for developing depression. Sometimes D was not enthusiastic and was feeling gloomy, he spent a lot of time in his room. $\mathrm{D}$ listened to music and played games to divert his attention. Not only when having the IBS symptoms, D occasionally and suddenly could show no enthusiasm in everything (W36). This made him often have difficulties to do something meaningful and positive (W63). Although D had a desire to rule the world, when he faced with a challenging situation, he preferred to avoid the situation by complaining. D's depression had not been revealed much qualitatively. By from the interview, D felt useless, he punched his stomach and face. D felt that IBS disturbed his life. His feeling useless was based on his childhood condition that was reinforced until now.

"I was once told 'this sick child, this stupid child brings problems to the family'. In the past, I was named that by others. One of them is my cousin that said 'Better kick him out, call the police', that's why with my cousin, I'm a bit reluctant." (D93)

"Saya kan pernah dibilang "halah anak sakitsakitan gini, halah anak bodoh bikin susah keluarga". Dulu saya kan pernah di cap gitu sama orang-orang. Saya pada akhirnya, salah satunya sepupu saya yang ngecap. "Halah mendingan diusir aja, dipanggilin polisi” makanya kalau saya sama sepupu itu agak gimana gitu." (D93)

\section{Irritable Bowel Syndrome, Stress, Anxiety, and Depression}

Chronic illness might be related to emotional factors, such as stress, anxiety, and depression (de Jonge, 2013; Ferguson, cited in Nauert, 2010; Quigley, 2009). Binimelis et al. (cited in Han, 2013) explain that there is a regulation between psychological factors and digestive functions, for example, movement and feeling are the results of the nervous system, endocrine, and immune system. Negative emotions, such as anxiety and depression, disrupt the cerebral cortex and limbic system. This affects the function of nervous system through the brain-gut axis and the neurohormonal system, causing a disorder in the secretion of gastrointestinal hormone. Then, this blocks the intestinal epithelium, mucosa immune dysfunction, strengthening of bowel movement, and triggers visceral sensitivity. As a result, it produces changes in the digestive function, causing diarrhea, constipation, or stomach pain, and IBS (Wouters \& Boeckxstaens, cited in Han, 2013).

Other research results explained the role of lo-cus ceruleus as the modulator of normal gastrointestinal function and the coordinator of emotional, physiological, and fear conditioning to react to danger (Tosic-Golubovic et al., 2010). Locus ceruleus plays a role in the relationships within the Central Nervous System (CNS) area that connects afferent and efferent nerves with the intestines. Locus ceruleus receives afferent nerve input from the 
intestines and triggers the pressure in the colon that increases the performance of locus ceruleus. Gastrointestinal symptoms (pain and cramps) increase the performance of CNS through afferent nerve input to the locus ceruleus which allows positive feedback cycle from the increase of CNS performance and uncontrolled gastrointestinal pressure. Tougas (2000) explains that the motility of digestive organs is also affected by the Autonomic Nervous System (ANS). The ANS is integrated anatomically and functionally with the visceral sensory pathway and is responsible for the regulation function of homeostatic intestines. Stressful condition causes abnormal stimulation of the gastrointestinal receptors. Abnormality in the responses of gastrointestinal receptors disrupts intestine motility. Ultimately, CNS sends abnormal stimulation ofthe gastrointestinal motility through efferent nerve pathways.

The mechanism of the relationships between stress, anxiety, and depression involves the interacttions between the Corticotripin-Releasing Factor Receptor 1 (CRFR1) and a specific type of serotonin receptor (5-HTRs). The 5-HTRs is an important neurotransmitter inside the Enteric Nervious System (ENS) and brain-gut axis. The 5-HTRs is also involved in several functions of the digestive system, including peristaltic reflexes. Peristaltic reflexes are contractions and relaxations of muscles forming a wave to pull and push food and drink into the intestine (Marieb, 2012). A large amout of serotonin is found in the digestive system (storing $80 \%$ of serotonin in the body), that is, $95 \%$ of serotonin is stored in the intestinal enteroendocrine cells and 5\% in the enteric neurons. The CRFR1 works for reducing the amount of 5-HTRs on the surface of cells in the brain that can cause abnormal signals. An activation of CRFR1 causes anxiety in human when responding to stress, while a deficiency of 5HTRs causes depression (Jacobsen, Medvedev, \& Caron, 2012), even though the role of psychological factors, whether it is the cause or the result of IBS disorder, is still not clear. The degree of relationships between psychological disorders and IBS symptoms have not yet understood because of multimechanism involvement (de Jonge, 2013).

\section{Limitations}

This study is based only on D's answers showing the presence of stress, anxiety, and depression using the DASS-21 assessment. During qualitative data collection, the researcher encountered difficulties to obtain consent from the significant others who frequently interacted with D at home. During data collection, D's mother seemed to be emotionally exhausted in dealing with $\mathrm{D}$ that often showed behavior leading towards anxiety and depression. This made the researcher have difficulties in validating the data collected from D. D responded to every question during the data collection but $\mathrm{D}$ sometimes provided irrelevant responses. D's answers were full of wandering ideas and main topics, for example, the ones related to his desire to rule and change the world, the threats he encountered including his relationship problems with others (friends and family), and the problems with academic works. Future research needs to conduct assessment on psychological aspects (stress, anxiety, and depression) using several inventories in order to describe IBS patients' psychological conditions, to include a case study with direct involvement with the patients' life, and to recheck the medical status of patients in relation to IBS.

\section{Conclusion}

The causal-relationships between IBS symptoms, anxiety, and depression is unfortunately still difficult to be explained clearly. Even Elsenbruch (cited in Gaber, 2016) explained the emergence of the speculation that IBS symptoms are caused by disturbances in psychological aspects and not physiological. The authors do not know whether IBS contributes to anxiety, stress, and depression. In several IBS patients, both emerge at the same time. Further studies need to be conducted to explore the possible connections.

\section{References}

Baum, A., \& Polsusnzy, D. (1999). Health psychology: Mapping biobehavioral contributions to health and illness. Annual Review of Psychology, 50, 137-163.

Carpenito, L. J. (2000). Buku saku diagnosis keperawatan (8th ed.) (M. Ester, Pengalih bhs). Jakarta: EGC.

Cash, B. D., Schoenfeld, P., \& Chey, W. D. (2002). The utility of diagnostic tests in irritable bowel syndrome patients: A systematic review. The American Journal of Gastroenterology, 97(11), 2812-2819.

Chang, L. (2011). The role of stress on physiologic 
responses and clinical symptoms in irritable bowel syndrome. Gastroenterology, 140(3), 761-765.

Chey, W. D., Kurlander, J., \& Eswaran, S. (2015). Irritable Bowel Syndrome: A clinical review. JAMA, 313(9), 949-958.

Clark, D. A., \& Beck, A. T. (2010). Cognitive therapy of anxiety disorders: Science and Practice. New York: The Guilford Press.

Creed, F., \& Guthrie, E. (1987). Psychological factors in the irritable bowel syndrome. Gut, 28(10), 1307-1318.

de Jonge, W. J. (2013). Review article: The Gut's little brain in control of intestinal immunity. Retrieved from: http://dx.doi.org/10.1155/2013/630 159 ISRN Gastroenterology, Vol. 2013 (2013), Article ID 630159, 17 pages.

Drossman, D. A., Camilleri, M., Mayer, E. A., \& Whitehead, W. E. (2002). AGA technical review on irritable bowel syndrome. Gastroenterology, 123(6), 2108-2131.

Farnam, A., Somi, M. H., Sarami, F., \& Farhang, S. (2008). Five personality dimensions in patients with irritable bowel syndrome. Neuropsychiatric Disease and Treatment, 4(5), 959-962.

Feist, J., \& Feist, G. J. (2009). Theories of personality (7th ed.). New York: McGraw-Hill.

Ford, A. C., Brandt, L. J., Young, C., Chey, W. D., Foxx-Orenstein, A. E., \& Moayyedi, P. (2009). Efficacy of 5-HT3 antagonists and 5-HT4 agonists in irritable bowel syndrome: Systematic review and meta-analysis. The American Journal of Gastroenterology, 104(7), 1831-1843. doi: 10.10 38/ajg.2009.223.

Fukudo, S., Hahm, K., Zhu, Q., Sollano, J. D., Rani, A. A., Syam, A. F., ...\& Arakawa, T. (2015). Survey of clinical practice for irritable bowel syndrome in East Asian countries. Digestion, 91, 99-109.

Gaber, O. H. (2016). The relationship between irritable bowel syndrome, depression, anxiety, and stress among sample of irritable bowel patientsPredictive Study. Journal of Psychology and Clinical Psychiatry, 5(4), 00290. DOI: 10.15406 /jpcpy.2016.06.00290

Graff, L. (2015). "Psychological Works" Fact Sheet: Irritable bowel syndrome. Winnipeg, Manitoba: Canadian Psychological Association.

Goldberg, J. (2014). The effects of stress on your body. Retrieved from http://www.webmd.com/b alance/stress-management/effects-of-stress-on-yo ur-body

Han. B. (2013). Correlation between gastrointestinal hormones and anxiety-depressive states in irritable bowel syndrome. Experimental and Therapeutic Medicine, 6(3), 715-720.

Jacobsen, J., Medvedev, I., \& Caron, M. (2012). The 5-HT deficiency theory of depression: Perspectives from a naturalistic 5-HT deficiency model, the tryptophan hydroxylase $2^{\text {Arg }} 439^{\text {His }}$ knock in mouse. Cardiovascular Training Program, 367 (1601), 2444-2459.

Kiamarsi, A., \& Abolghasemi, A. (2010). Emotional intelligence and frustration: Predictors of quality of life in patients with irritable bowel syndrome. Procedia Social and Behavioral Sciences, 5, 827-831. Retrieved from http://dx.doi.org/10.1 016/j.sbspro.2010.07.193

Lahey, B. B. (2007). Psychology: An introduction (9th ed.) New York: McGraw-Hill.

Lovibond, S. H., \& Lovibond, P. F. (1995). Manual for the depression anxiety stress scales (2nd ed.) Sydney: Psychology Foundation.

Makharia, A., Catassi, C., \& Makharia, G. K. (2015). The overlap between irritable bowel syndrome and non-celiac gluten sensitivity: A clinical dilemma. Nutrient, 7, 10417-10426. doi:10.3390/nu 7125541

Malagelada, J. R. (2006). A symptom-based approach to making a positive diagnosis of irritable bowel syndrome with constipation. International Journal of Clinical Practice, 60(1), 57-63.

Manning, A. P., Thompson, W. G. , Heaton, K. W. , \& Morris, A. F. (1978). Towards a positive diagnosis of the irritable bowel syndrome. British Medical Journal, 2(6138), 653-654.

Marieb, E. N. (2012). Essentials of human anatomy and physiology (10th ed.). Boston: Benjamin Cummings.

Nauert, R. (2010). Link between stress, anxiety, depression. Retrieved from http://psychcentral. com/news/2010/04/12/link-between-stressanxiety depression/12749.html

Quigley, E. (2009). Irritable bowel syndrome: A global perspective. Retrieved from: http://www. worldgastroenterology.org/guidelines/global-guid elines/irritable-bowel-syndrome-ibs/irritable-bow el-syndrome-ibs-english

Sarafino, E. P. (2006). Health psychology: Biopsychosocial interaction (5th ed.). New Jersey: John Wiley \& Sons, Inc.

Schultz, D. (1986). Psychoanalytic approach: Sigmund Freud in theories of personality (3rd ed.) California: Brooke/Cole.

Stuart, W. Z., \& Sundreen, S. J (1998). Buku saku ke- 
perawatan jiwa (3rd ed.) (A.Yani, Pengalih bhs.) Jakarta: EGC.

Thompson, J. R. (2016). Is irritable bowel syndrome an infectious disease? World Journal of Gastroenterology, 22(4), 1331-1334. doi: 10.37 48/wjg.v22.i4.1331.

Tosic-Golubovic. S., Miljkovic, S., Nagorni, A., Lazarevic, D., \& Nikolic, G. (2010). Irritable bowel syndrome, anxiety, depression, and personality characteristics. Psychiatria Danubina, 22(3), 418-424.

Tougas, G. (2000) The autonomic nervous system in functional bowel disorders. Gut, 47, 78-80.

Wald, A. (2016). Patient education: Irritable bowel syndrome (beyond the basics). Retrieved from http://www.uptodate.com/contents/irritable-bowe l-syndrome-beyond-the-basics

Wilson, A., Longstreth, G., Knight, K., Wong, J., Wade, S., Chlou, C..., \& Othman, J. (2004). Quality of life in managed care patients with ir-ritable bowel syndrome. Manage Care Interface, 17, 24-28.

World Gastroenterology Organization. (2015). Irritable bowel syndrome: Global perspective. Retrieved from http://www.worldgastroenterology.o rg/guidelines/global-guidelines/irritable-bowel-sy ndrome-ibs/irritable-bowel-syndrome-ibs-english Zeitner, M. (1998). Test anxiety: The state of the art. NewYork: Kluwer Academic Publishers. 